\title{
Panamanian Start-ups that Propel Research and Higher Learning
}

\section{LAURDS International Conference: Perspectives on Culture, Research Strategies and Doctoral Studies in Latin America Panama City, Panama July 26-27, 2018}

\author{
1,2,*Nanette Archer Svenson, ${ }^{3}$ Gladys Bernett, ${ }^{4}$ Guillermina de Gracia, \\ ${ }^{1,2}$ Nadia De Leon, ${ }^{5}$ Debbie Psychoyos and ${ }^{6}$ K. S. Jagannatha Rao \\ ${ }^{1}$ Researcher, Centro de Investigación Educativa (CiEdu), Ciudad del Saber, Panamá. \\ ${ }^{2}$ Associate Researcher, Universidad Católica Santa María La Antigua (USMA), Panamá. \\ ${ }^{3}$ Researcher, USF Health Panamá, Ciudad del Saber, Panamá \\ ${ }^{4}$ Researcher, Asociación de Antropología e Historia de Panamá (AAHP), Panamá \\ ${ }^{5}$ Fundación ProEd, Panamá \\ ${ }^{6}$ Director, Instituto de Investigaciones Avanzadas y Servicios de Alta Tecnología (INDICASAT), \\ Ciudad del Saber, Panamá. \\ *Autor para correspondencia. Email: nanette.svenson@gmail.com
}

Recibido: 14 de agosto de 2018

Aceptado: 22 de octubre de 2018

\begin{abstract}
Resumen
La República de Panamá puede presumir de un aumento constante del PIB con una de las tasas de crecimiento económico más altas de la región, un sector de servicios internacionales en expansión, sistemas financieros y bancarios sólidos, y una relativa estabilidad política y seguridad ciudadana. Desafortunadamente, ninguna de estas ventajas ha conducido a un sistema educativo sólido o a una extensa agenda de investigación y desarrollo. Tanto en educación como en investigación, Panamá se encuentra entre las más bajas tasas de la región, en estos órdenes. Sin embargo, algunas iniciativas avanzadas en la última década son prometedoras en cuanto a cambiar esta tendencia, al menos en ciertos sectores. Este documento explora varios de estos esfuerzos, todos los cuales involucran componentes internacionales sólidos con respecto a las alianzas, la transferencia de conocimientos y la programación colaborativa que contribuyen a la sostenibilidad de estos programas, el desempeño en línea con los estándares establecidos a nivel mundial y el papel en el desarrollo de la capacidad nacional. Estas iniciativas innovadoras son las siguientes: 1) INDICASAT, un instituto público-privado de investigación científica y servicios de alta tecnología que se concentra en el estudio biomédico; 2) la Fundación ProEd, una organización no gubernamental local que ha desarrollado e implementado el único programa de capacitación de maestros K-12 basado en estándares internacionales reconocido por el Ministerio de Educación; 3) el programa de University of South Florida Health Panama en Ciudad del Saber, que desarrolla cursos regionales e investigación internacional en áreas relacionadas con la salud pública y la educación; 4) la Asociación Panameña de Antropología e Historia, una asociación académica joven que está impulsando y promoviendo la investigación en las ciencias sociales; y 5) CIEdu, un nuevo concepto que se está desarrollando actualmente para un Centro nacional e independiente de investigación para la educación. El documento concluye con recomendaciones para apoyar este tipo de nuevas empresas impulsadas por la investigación y ampliar su potencial
\end{abstract}


Invest. pens. crit. (ISSN 1812-3864)

Vol. 6, No. 3, septiembre- diciembre 2018

pp. 68-79

de colaboración. También destaca cómo la Ciudad del Saber de Panamá, una zona franca internacional de educación, está en una posición única para impulsar estas iniciativas de educación superior para el país y la región.

Palabras Clave: Investigación científica, Educación Superior, Emprendimientos, Innovación, Ciudad del Saber, Panamá.

\begin{abstract}
The Republic of Panama can boast of a steadily rising GDP with among the highest economic growth rates in the region, an expanding international services sector, robust financial and banking systems, and relative political stability and citizen security. Unfortunately, none of these advantages has led to strong education system or an extensive research and development agenda. In both education and research, Panama ranks among the lowest in the region. Nevertheless, certain initiatives advanced over the past decade show promise for shifting this tendency, at least in certain sectors. This paper explores several of these endeavors, all of which involve strong international components with regard to partnerships, knowledge transfers and collaborative programming that serve to contribute to these programs' sustainability, performance in line with globally established standards, and role in national capacity development. These innovative initiatives are the following: 1) INDICASAT, a public-private institute for scientific research and high technology services that concentrates on biomedical study; 2) the ProEd Foundation, a local non-governmental organization that has developed and implemented the only international standard driven K-12 teacher training program recognized by the Ministry of Education; 3) the University of South Florida Health Panama program at the City of Knowledge that develops regional courses and international research in areas related to public health and education; 4) the Panamanian Association for Anthropology and History, a young academic association that is driving and promoting research in the social sciences; and 5) CIEdu, a new concept currently being developed for a national, autonomous Center for Education Research. The paper concludes with recommendations for supporting these types of research-driven start-ups and expanding their collaborative potential. It also highlights how Panama's City of Knowledge, an international education free-zone, is uniquely positioned to propel these higher learning initiatives for the country and the region.
\end{abstract}

Keywords: Scientific Research, Higher Education, Startups, Innovation, City of Knowledge, Panamá.

\title{
Introduction
}

The Republic of Panama is a land of contrasts, in ways that are both positive and negative. One of the sharpest and most paradoxical of its negative disparities is the fact that over the past several decades Panama has had one of the highest economic growth rates in Latin America, alongside one of the weakest education systems in the region. Panama enjoys a steadily rising GDP, an expanding international services sector, robust financial and banking systems, relative political stability, and strong citizen security. But none of these national advantages has led to a world-class education system or robust research and development agenda. Without strong fundamentals in education and research, Panama's upwardly inclined economic trajectory would seem to be threatened. 


\section{The Panamanian education and research context}

The table below presents these two realities with selected indicators for Panama's economic and education situations, juxtaposed against the same situational indicators for Chile, a leader in the Latin American region with regard to both economic and education development, and the US and Finland, two distinct models from the Organization for Economic Cooperation and Development (OECD) countries. Panama fairs reasonably well with regard to gross national income (GNI) per capita, at least compared with Chile, but its GINI coefficient indicates a high degree of inequity within the country — even within a region infamous for income inequality. The gap widens between overall national economic success and the potential for individual success within Panama when we look at the education indicators. Though Panama and Chile, along with most OECD countries, have achieved near universalization of primary education completion, the statistics for access and completion shift significantly at the higher levels. At both high school and post-secondary levels, Panamanian enrollment figures are far below Chile's, not to mention those of the US and Finland-and though completion data is extremely limited, rates are estimated to be much lower (Table 1).

Table 1

Selected statistics, economic and education comparisons, 2018

\begin{tabular}{|l|c|c|c|c|c|}
\hline & $\begin{array}{c}\text { GDP per } \\
\text { capita } \\
\text { (USD) }\end{array}$ & $\begin{array}{c}\text { GINI } \\
\text { index }\end{array}$ & $\begin{array}{c}\text { Net HS } \\
\text { enrollment }\end{array}$ & $\begin{array}{c}\text { Gross } \\
\text { HE } \\
\text { enrollment }\end{array}$ & $\begin{array}{c}\text { PISA } \\
\text { average }\end{array}$ \\
\hline Panama & 15,088 & 50.4 & 70 & 47 & 369 \\
\hline Chile & 15,347 & 47.7 & 87 & 90 & 443 \\
\hline USA & 59,532 & 41.5 & 91 & 89 & 488 \\
\hline Finland & 45,703 & 27.1 & 96 & 87 & 523 \\
\hline
\end{tabular}

Source: World Bank Open Data, 2018

Added to this, Panama's education quality at all levels is a grave concern. Evidence of this is reflected in the most recent scores on the Programme for International Student Assessment (PISA), a worldwide OECD study conducted in both member and non-member countries to evaluate educational systems by measuring 15 -year-old students' performance on mathematics, science, and reading assessments. As shown in Table 1 above, compared to Panama, Chile's PISA scores are 20 higher, with the US and Finnish scores, respectively, 32 and 40 percent above those of Panama. This does not speak well for the Panamanian education system and given Panama's reliance on global activity for a large part of its national production, it does not bode well for the country's competitiveness.

This unfortunate scenario is intrinsically related to Panama's higher education and research capacity. While there has been significant growth in the number of universities established from the 1990s onward-beyond the five public universities and single Catholic university-most of this growth has been in the for-profit sector and without stringent national quality assurance systems in place. Today, there are over 100 universities listed in Panama's public registry; of these, less than half are recognized by the authorities and fewer than that are accredited by the national 
Invest. pens. crit. (ISSN 1812-3864)

Vol. 6, No. 3, septiembre- diciembre 2018

pp. 68-79

accreditation council (Consejo Nacional de Evaluación y Acreditación Universitaria de Panamá, CONEAUPA) or by international accreditation agencies (Arjona, 2009; Svenson \& De Gracia, 2017).

Thus, Panama now faces an oversupply of higher education institutions, an undersupply of credentialed professors, an incipient quality assurance system, stagnant enrollment growth, low completion rates and miserable (not far above minimum wage) starting salaries for graduates (Svenson \& De Gracia, 2017). All of this works to thwart research efforts, which even among the accredited institutions are extremely limited.

According to 2013 figures provided by the UNESCO Institute for Statistics (UIS), only two percent of the Panamanian population holds a Master's degree and an almost negligible 0.3 percent holds a doctorate degree (UIS, 2017). Without adequate graduate and post-graduate knowledge and training in Panamanian academia, it is difficult to develop much of a research culture. Also, the resources for funding research are minimal. In the past decade, Panama has invested only between 0.1 and 0.2 of its gross national product (GDP) in research and development (UIS, 2017).

That is roughly 20 times less than what an OECD country invests on average. Juxtaposed against worldwide trends for R\&D investment, examining researchers per million inhabitants and $R \& D$ expenditures as a percentage of GDP, Panama looks even worse and appears quite literally at the bottom of the world (Figure 1).

And if lack of training and resources were not sufficient to deter research efforts, the traditionally teaching orientation of Panamanian higher education would provide the nail in the coffin. Most professors, even those with Master's or doctorates, are typically forced to spend so much of their time teaching-often between multiple institutions-that contemplating any meaningful dedication to investigative activity is practically financially impossible.

Figure 1

$\mathrm{R} \& \mathrm{D}$ spending by country

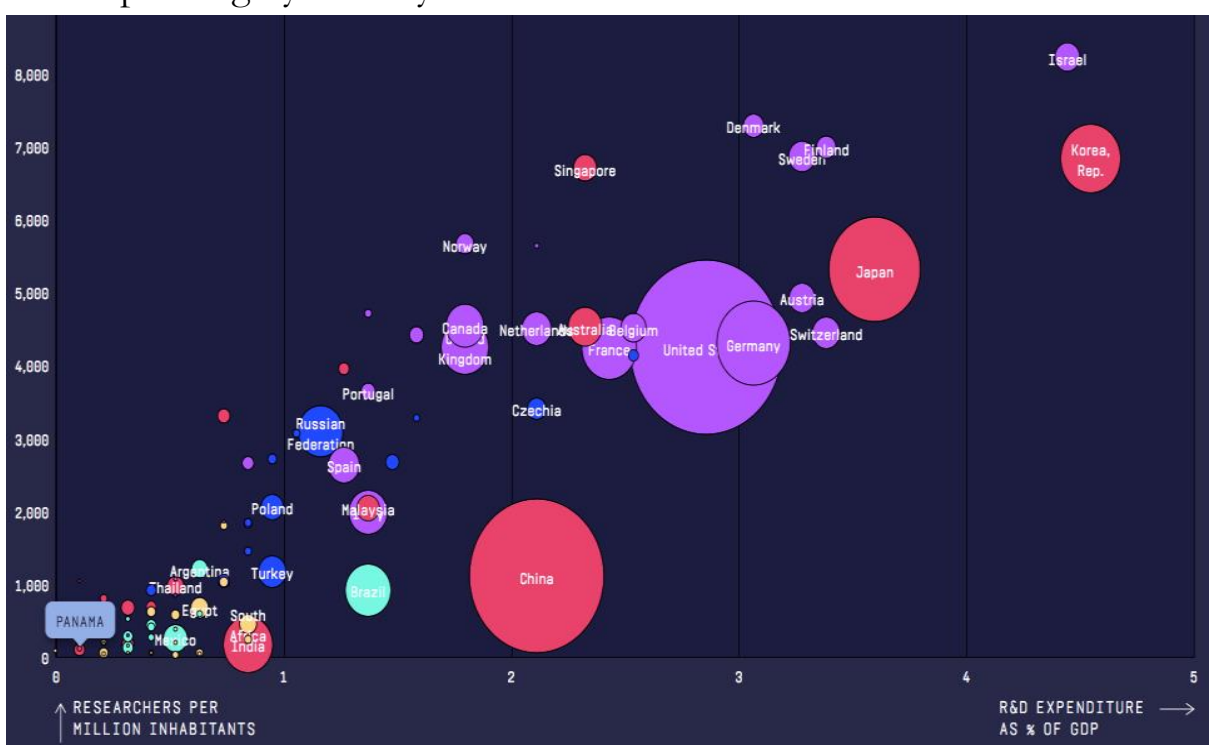

Source: UNESCO Institute of Statistics (UIS), 2017 
Invest. pens. crit. (ISSN 1812-3864)

Vol. 6, No. 3, septiembre- diciembre 2018

pp. 68-79

\section{Examples of exceptional start-ups}

In spite of the challenges to higher education and research in Panama presented above, certain initiatives advanced over the past decade show promise for shifting this tendency, at least in some niche areas. This section explores several of these endeavors, all of which operate through different legal and organizational modalities: INDICASAT, a national public-private institute for scientific research and high technology services that concentrates on biomedical study and clinical trial coordination; the ProEd Foundation, a local non-governmental organization (NGO) that has developed and implemented the only international standard driven K-12 teacher training program in the country recognized by the Ministry of Education; the University of South Florida (USF) Health Panama program at the City of Knowledge that develops regional courses and international research in areas related to public health issues and education systems; the Panamanian Association for Anthropology and History, a young academic association that is driving research in the social sciences; and CIEdu, a new concept currently being developed for a national, autonomous Center for Education Research (Centro de Investigación Educativa). The following sub-sections offer additional description on these enterprising outliers.

\section{INDICASAT}

INDICASAT (Instituto de Investigaciones Científicas y Servicios de Alta Tecnología), a publicprivate institute for scientific research, was originally established in 2002 as a government agency and became an "association of public interest (AIP)" in 2008 to allow for receipt of tax-exempt donations for research purposes and provision of technical services for corporate as well as government entities under SENACYT, Panama's national secretariat for science, technology and innovation. Shortly after INDICASAT's conversion to AIP status, the decision was taken to hire an international director in an effort to boost cross-border connections and the incorporation of international research standards and protocols. Dr. Jagannatha Rao, originally from India, was selected for the position and continues to head INDICASAT today (INDICASAT, 2018). He also holds adjunct faculty and board advisory positions in US universities and serves on the editorial board of 25 academic journals, all of which has enabled the development and strengthening of INDICASAT's global reach.

INDICASAT concentrates on biomedicine and biodiversity but also incorporates an array of interdisciplinary studies in its mission is to serve as a platform for the advancement of science and technology in Panama and formation of research capacity in areas crucial for national and regional development. INDICASAT now has one of the most complete biochemical research installations in all of Central America with 30 full time scientists, 40 doctoral students, 25 undergraduate and Master's students, 30 international and 25 national adjunct faculty members and one Nobel laureate. It has over 40 clinical investigations currently underway and has registered more than 300 peer-reviewed publications to date. It has received dozens of international recognitions and awards in the past decade along with 50 research grants from SENACYT and has registered four patents (Rao, 2018).

Through the development of numerous international academic partnerships, INDICASAT has become one of Panama's primary producers of scientific Master's and PhDs. Partner institutions for joint doctoral and graduate degrees and research include the University of Texas-El Paso (UTEP) in the US, Acharya Nagarjuna University in India, Beijing Genomics Institute (BGI) in China and the International Centre for Genetic Engineering and Biotechnology (ICGEB) in Italy. With regard to ICGEB, INDICASAT now hosts the ICGEB-Regional Research Centre in Panama, unique for Latin America. INDICASAT is also working with local universities to integrate some of this knowledge transfer and doctoral training into existing national programs. For 
Invest. pens. crit. (ISSN 1812-3864)

Vol. 6, No. 3, septiembre- diciembre 2018

pp. 68-79

example, its $\mathrm{MD}-\mathrm{PhD}$ in biomedicine with the University of Panama offers a three-year program in English - the first of its kind in Latin America-with one year of study in Panama and two years abroad. Similarly, joint $\mathrm{PhD}$ programs in biotechnology and bioscience are currently being discussed with the Universidad Tecnológica de Panamá (UTP). INDICASAT has also developed a broader strategic plan for a national Biotech Park, which it is beginning to carry forward (Rao, 2018).

INDICASAT furthers these efforts by active engagement with academic conferences and hosted the international Conference on Biomedicine and Interdisciplinary Science with UK funding in Panama in February of 2016. It has also been invited to present at the upcoming World Expo 2020-Dubai as a model institute. INDICASAT is working toward making Panama a scientific hub for the region and showing how this reality can be accelerated through dynamic utilization of international partnerships and programming.

\section{ProEd Foundation}

An unfortunate reality of Panama's weak education system manifests in the great disparities evident between the public and private schools. From major differences in infrastructure and instruction to standardized test scores and employment opportunities, Panamanian public school students are failing to make the grade. A large part of this has to do with teaching and administrative capacity.

Established in 2002, the ProEd Foundation (Fundación ProEd), a local NGO with a mission to support and improve education in Panama, has turned its focus over the past decade to bridging educational inequality through the continuous professional development of teachers and school leaders. Toward this end, ProEd has pioneered a number of modular courses designed to systematically educate educators on international standard pedagogy, methods and strategies. The Panamanian Ministry of Education (MEDUCA) recognizes and credits ProEd programming in its teacher evaluation system and both MEDUCA and SENACYT have partnered with ProEd on numerous occasions. ProEd's most recently launched initiative, the New Teacher Certification Program: Innovative Strategies for Teachers, offers a course with a broader focus, deeper experience, more longterm perspective and a weightier qualification. Seeking to create a new generation of teacher's adept in leadership and active learning, this program operates over a 10-month period and provides 220 hours of theory, demonstration, practice, feedback and coaching (Joyce \& Showers, 2002; ProEd 2018). The hope is to scale this program through MEDUCA and train increasing percentages of the public school educators.

Over the past five years, ProEd has also incorporated research and scientific metrics to measure its efforts using World Bank and Gates Foundation methods and indicators. The results of these studies imply that students trained by ProEd teachers are superior to those of students taught by teachers not trained by ProEd. Using inputs from Stanford, Harvard, the University of Missouri and others, ProEd equips teachers with effective state-of-the-art tools for facilitating learning in all grades. More importantly, ProEd facilitators, trained in Panama and abroad, teach and monitor these programs locally (Psychoyos, 2018).

In acknowledgement of these successes, ProEd has won multiple prizes. In 2014, they received the UNESCO Hamdan bin Rashid Al-Maktoum Prize for Outstanding Practice and Performance in Enhancing the Effectiveness of Teachers; in 2015, ProEd was a top four finalist (out of 800) for the Latin American ALAS Foundation-Inter-American Development Bank prize for Best Educational Innovation; in 2012, ProEd's founder and CEO, Dr. Debbie Psychoyos, was selected as one of Panama's National Heroes, a social engagement recognition; and also in 2012, ProEd 
Invest. pens. crit. (ISSN 1812-3864)

Vol. 6, No. 3, septiembre- diciembre 2018

pp. 68-79

won the HSBC Future First prize. Alongside these accolades, in Panama's recent National Competition for Excellence in Education (Concurso Nacional por la Excelencia Educativa), which awards schools for academic achievement, three of the finalists were centers with ProEd trained teachers (Psychoyos, 2018). While still a start-up and struggling to scale its reach and impact, ProEd is an example of what can be achieved-through the application of international research, methods and partners - for advancing research and higher learning in the education sector.

\section{USF Health Panama}

The University of South Florida (USF), ranked in the top 50 US research universities, ninth among public institutions and $21^{\text {st }}$ worldwide for those granted US utility patents, opened the USF Health Panama program in 2006. Dr. Arlene Calvo, a Panamanian alumna of the USF College of Public Health, established its offices in Panama's City of Knowledge as a non-profit foundation with a mission to expand education, research, and professional development opportunities for students and faculty from USF and partner higher learning/research institutions. Its aim has been to build capacity for sustainable development in Panama and Latin America.

Since 2006, the USF Health Panama program has signed numerous collaborative agreements, engaged over 1,300 USF and 300 non-USF student participants (nearly three quarters from the health sector) in international field experience, study abroad and research programs, and appointed eight Panamanian affiliate faculty members. It has trained over 2,000 Panamanian health and education professionals through conferences, workshops, seminars and continuing education programs and has executed over \$1.6 million in local and international research and program grant funding. It has also facilitated the channeling of a number of Panamanian scholars (funded by the government through SENACYT) to the USF College of Public Health in Tampa for completion of Master's and doctoral degrees (Bernett, 2018).

The USF Health Panama program provides local and international faculty and students an opportunity for knowledge exchange in research, public health instruction and specialized clinical training. It also conducts hands-on training and population-based research in at-risk and vulnerable communities of Panama. The USF Health Panama program includes a strong network of local collaborators, such as the Gorgas Memorial Health Research Institute, INDICASAT, SENACYT, the University of Panama and the City of Knowledge, as well as various international public and private partners. They work closely with indigenous, inner city and semi-rural communities to transfer healthcare learning and know-how, focusing mainly on a range of women's and infant health issues. Programming includes work with shelters for high-risk pregnant women, training of lay midwives and capacity building for Ministry of Health nurses and other health professionals (Bernett, 2018; Calvo and Rebollón, 2018).

The USF Health Panama program also organizes and supports national and international conferences and symposia on topics ranging from vaccine research to nursing practice to infectious disease. In 2017 with faculty support from the USF College of Public Health Policy Department, an international training session was offered on big data to explore use of electronic medical records for monitoring public health, treatments and outcomes. The event was well received and attended by health practitioners from the Gorgas Institute, the national Social Security system, private practice, City of Knowledge, NGOs and pharmaceutical companies. Likewise, in 2018, the USF Health Panama program offered medical simulation certification training to 40 Panamanian public health clinicians at USF in Tampa. Alongside the instructional and research work, the USF Health Panama projects have produced numerous academic publications (Bernett, 2018; Calvo and Rebollón, 2018). 
Invest. pens. crit. (ISSN 1812-3864)

Vol. 6, No. 3, septiembre- diciembre 2018

pp. 68-79

Current USF Panama efforts have begun to include collaborations with the USF College of Education as well. A recent project with local partners focused on improved mathematical modeling for standardized tests and production of data for public policy decisions. Another project introduced a series of teacher training and coaching initiatives in the area of science related instruction for over 100 public schools throughout Panama.

\section{Panamanian Association of Anthropology and History}

The Panamanian Association of Anthropology and History (AAHP, for its acronym in Spanish) was officially established in 2015 in response to recommendations put forth during the first Panamanian Anthropology Conference in 2013 and has quickly grown to attract scholars from multiple disciplines of the social sciences. With 38 permanent members and affiliates in both local and international universities, the AAHP is beginning to fill a void in Panama's academic community (AAHP, 2018; De Gracia, 2018).

Professional associations worldwide are non-profit organizations founded with the express aim of furthering the indicated profession in terms of current state-of-the-art practice, networking opportunities, communications and visibility. In academia, these associations form around a specific discipline or collection of disciplines and typically propel inter-institutional collaboration, research dissemination, knowledge exchange and professional development. Unfortunately, little of this exists in Panama for any academic disciplines. Within the social sciences, especially, there is a very limited research culture, few platforms or spaces for the dissemination of research results, and a lack in the continuity and regularity of dissemination proposals (De Gracia, 2018).

In its first few years of operation, the AAHP is beginning to address these issues. Its organizational objectives are to bring together professionals in the disciplines of anthropology, history, their respective sub-disciplines, and other related areas of scientific study; to offer an official channel for communication of the informed opinions of its members and associates; drive the development of and work produced by these academic areas; and foster and promote research on, communications related to, and protection of the country's cultural patrimony (AAHP, 2018; De Gracia, 2018). A follow-up international conference was implemented in 2016 with far greater funding, many more participants, and a much broader range of research presentations. Similar plans are ongoing for a 2019 event. Other smaller events have been co-sponsored with local and international universities, research projects have been launched with SENACYT and the City of Knowledge, among others, and AAHP has facilitated international conference participation as well for its members.

Challenges to AAHP sustainability and growth are comparable to those of the other professional organizations in every country: the constant fundraising necessary for new research projects; promotion of improved participation, commitment and contribution among its members; and increased frequency and quality of its activities related to capacity development and research dissemination.

\section{CIEdu}

The concept for Centro de Investigación Educativa (CIEdu), an independent center in Panama that focuses on education research, is relatively new. Over the past two years, several leaders involved with diverse individual efforts to conduct and convey research on education at various levels have come together and begun to develop ideas for the operational objectives of such a body. To date, this endeavor has been loosely configured and enacted with the hope that through 
Invest. pens. crit. (ISSN 1812-3864)

Vol. 6, No. 3, septiembre- diciembre 2018

pp. 68-79

the articulation and promotion of goals, priorities and possible structures, a more permanent organization may evolve.

The idea is to convene education professionals and organizations-national and international, public and private - that are already engaged in research for promoting (1) the production of more independent, empirical, solutions-oriented work on specific priority issues in Panamanian education, and (2) informative communications on such research that has the potential to propel better decision-making, public policy and education practice. Targeted objectives for CIEdu include the following:

- Generation of a collective national research agenda

- Establishment of an Education Research Association

- Expansion of international partnerships to drive education research

- Provision of continuous learning opportunities and training for researchers

- Increased media coverage for both CIEdu and its work

- Production of policy briefs and white papers on priority issues

- Participation in pertinent national and international conferences (De Leon, 2018).

Possibilities for a sustainable CIEdu structure include a Panamanian AIP (Asociación de interés publica), a public-private research center jointly funded by government and private sector sources; a national or regional not-for-profit non-governmental organization (NGO); and a private foundation, among others. Steps toward this end will begin in earnest now that CIEdu recently won one of the 2018 SENACYT grants awarded to expand and develop national think tanks for better informed public policy. Regardless of modality, the main challenges will be to secure sufficient, continuous financing for CIEdu activity and attract/train the necessary human resource base.

\section{Conclusion and recommendations}

The mini case studies presented above on INDICASAT, ProEd, USF Health, AAHP and CIEdu demonstrate that it is possible to develop world-class, international standard academics and research in Panama. In just over a decade, these programs have begun to revolutionize higher learning and research capacity for the country and collectively have trained hundreds of highly qualified professionals. With increased support and continued integration into national education systems, these programs and others like them hold considerable hope for advancing Panamanian higher education and research.

Returning to the paradox with which this paper began, Panama is not a poor country and therefore should not have poor education and research systems. This is neither justifiable nor intelligent from the perspective of national development strategy, especially for the long term. Failing to invest adequately in education and research not only extends the acute income inequality and social exclusion already apparent in Panamanian society but also jeopardizes future national competitiveness.

Despite Panama's rather bleak performance in education, particularly at the higher levels and for $\mathrm{R} \& \mathrm{D}$, there are significant efforts underway that are producing results, as the start-ups described above exemplify. These types of initiatives need to be recognized, supported and expanded. And in spite of the challenges detailed here, Panama has numerous resources at its disposal with which to propel its burgeoning higher learning and research advances. 
Invest. pens. crit. (ISSN 1812-3864)

Vol. 6, No. 3, septiembre- diciembre 2018

pp. 68-79

First and foremost, given its high middle-income status along with its increasing GDP and tax base, Panama's government must increase investment in education and, especially, R\&D, where current expenditures are ridiculously low. This should be done beyond MEDUCA and SENACYT to include other government bodies such as the ministries of foreign affairs, social development and commerce, among others, and with sufficient oversight systems linked to desired results. Also, efforts should be made in connection with and alongside government spending to propel private sector investment in research. Panama has little experience (or tax incentive structures) with which to further this but must contemplate modernization of legislation in this regard.

Additionally, stronger support for and better utilization of the City of Knowledge could also serve to leverage national and regional R\&D efforts. The City of Knowledge, a former US military base located beside the Panama Canal's Pacific entrance, is now a private foundation led educationresearch-human development center. Its mandate and operating platform, which is an education free-zone legally separate from both MEDUCA and University of Panama bureaucracy and inefficiencies, already serve to channel and develop both public and private research financing and this activity could be expanded considerably. This is all the more reasonable a proposition given the array of international organizations and education institutions based there. The City of Knowledge's de facto housing of the humanitarian hub for Latin America and the Caribbean make it a valuable (and highly underutilized) knowledge resource (City of Knowledge, 2018; Svenson \& Montoto, 2012). Similarly, more dynamic administration of SENACYT funds, better linkage of these with national development priorities and improved dissemination of the results produced would also leverage the existing $\mathrm{R} \& \mathrm{D}$ activity and valid work beginning to get off the ground.

Interestingly, all of the start-ups discussed in this paper are situated within and/or work closely with both the City of Knowledge and SENACYT. The City of Knowledge is uniquely positioned to support these and similar initiatives to push forward research and higher learning in the country and in the region. SENACYT as an autonomous national public entity could be an even stronger partner in this effort with more fluid administration of its mission and resources. All of these ends, and more, must be explored quickly and committedly if Panama is to maximize its human resource development, further its research capacity and preserve its national competitiveness. Ignoring this imperative will doom Panama to developing country stagnation and waste its immense potential for bettering the lives of its own citizens as well as those of its neighbors in the surrounding region.

\section{References}

Arjona, E. (2009). Globalización del sistema universitario de Panamá: Naturaleza, causas, consecuencias y futuras implicaciones (Globalization of the Panamanian university system: Nature, causes, consequences and future implications). Retrieved from

https://www.academia.edu/22527317/Globalizaci $\% \mathrm{C} 3 \% \mathrm{~B} 3 \mathrm{n}$ de las Universidades en Panam $\% \mathrm{C} 3 \% \mathrm{~A} 1$.

Asociación de Antropología e Historia de Panamá (AAHP). (2018). La Asociación. Retrieved from http://aahpanama.org/asociacion/.

Bernett, G. (2018). USF Health Panama. Presented at the LAURDS International Conference: Perspectives on Culture, Research Strategies and Doctoral Studies in Latin America. Panama City, Panama, July 26-27, 2018. 
Calvo, A. \& Rebollón, A. (2018). Improving maternal health status in indigenous communities of Panama: Community-based participatory research and interventions among the Ngäbe-Buglé people of Panama. Chapter in Maternal health, pregnancy-related morbidity and death among indigenous women of Mexico and Central America: An anthropological, epidemiological and biomedical approach. D.A. Schwartz (ed).

City of Knowledge. (2018). About us. Retrieved from http://ciudaddelsaber.org/en.

De Gracia, G. (2018). Las asociaciones profesionales y su papel en el fomento de la cultura de la investigación (Professional associations and their role in the development of a research culture). Presented at the LAURDS International Conference: Perspectives on Culture, Research Strategies and Doctoral Studies in Latin America. Panama City, Panama, July 26-27, 2018.

De Leon, N. (2018). Generando y comunicando investigación para una educación basada en evidencia (Generating and communicating research for evidence-based education). Presented at the LAURDS International Conference: Perspectives on Culture, Research Strategies and Doctoral Studies in Latin America. Panama City, Panama, July 26-27, 2018.

Fundación ProEd (2018). Programs. Retrieved from http://www.fundacionproed.org/.

INDICASAT (Instituto de Investigaciones Científicas y Servicios de Alta Tecnología de Panamá). (2018). History and objectives. Retrieved from http://indicasat.org.pa/about-us/.

Joyce, B. \& Showers, B. (2002). Student achievement through staff development. Association for Supervision and Curriculum Development.

Psychoyos, D. (2018). The implementation of international standard driven teacher training in Panama. Presented at the LAURDS International Conference: Perspectives on Culture, Research Strategies and Doctoral Studies in Latin America. Panama City, Panama, July 26-27, 2018.

Rao, J. (2018). INDICASAT: Research and education with a view to innovation. Presented at the LAURDS International Conference: Perspectives on Culture, Research Strategies and Doctoral Studies in Latin America. Panama City, Panama, July 26-27, 2018.

SENACYT (Secretaría Nacional de Ciencia, Tecnonolgía e Innovación) (2018). Retrieved from http://www.senacyt.gob.pa/sobre-nosotros/.

Svenson, N. \& Montoto, L. (2012). Universities and the knowledge hubs of the developing world: An in-depth look at the City of Knowledge in the Republic of Panama. Educación Global 16: 53-69.

Svenson, N. \& De Gracia, G. (2017). Las ciencias sociales en la República de Panamá: Oferta en la academia versus demanda del mercado laboral (The social sciences in the Republic of Panama: Academic supply versus labor market demand). Retrieved from http://aahpanama.org/2017/06/las-ciencias-socialesen-la-republica-de-panama-oferta-en-la-academia-versus-demanda-del-mercado-laboral/.

UNESCO Institute for Statistics. (2018). Education and Literacy. Retrieved from http://uis.unesco.org/. 
Invest. pens. crit. (ISSN 1812-3864)

Vol. 6, No. 3, septiembre- diciembre 2018

pp. 68-79

UNESCO Institute for Statistics. How much does your country invest in R\&D? Retrieved from http://uis.unesco.org/apps/visualisations/research-and-development-spending/.

University of South Florida (USF) Health Panama (2018). Services. Retrieved from http://health.usf.edu/international/panama/our-services.

World Bank Open Data. (2018). Education Statistics (EdStats). Retrieved from http://datatopics.worldbank.org/education/. 